Portland State University

PDXScholar

Summer 8-27-2013

\title{
Division of Labor within the Household: The Experience of Bosnian Immigrant Women in Portland, Oregon
}

Miro Paljevic

Portland State University

Follow this and additional works at: https://pdxscholar.library.pdx.edu/open_access_etds

Part of the Sociology of Culture Commons

Let us know how access to this document benefits you.

Recommended Citation

Paljevic, Miro, "Division of Labor within the Household: The Experience of Bosnian Immigrant Women in Portland, Oregon" (2013). Dissertations and Theses. Paper 1421.

https://doi.org/10.15760/etd.1420

This Thesis is brought to you for free and open access. It has been accepted for inclusion in Dissertations and Theses by an authorized administrator of PDXScholar. Please contact us if we can make this document more accessible: pdxscholar@pdx.edu. 
Division of Labor within the Household: The Experience of Bosnian Immigrant Women in Portland, Oregon

by

Miro Paljevic

A thesis submitted in partial fulfillment of the requirements for the degree of

\author{
Master of Science \\ in \\ Sociology
}

Thesis Committee:

Alex Stepick, Chair

Maura Kelly

Amy Lubitow

Portland State University

2013 
(C) 2013 Miro Paljevic 


\begin{abstract}
This research study examines the impact of international migration of household labor for Bosnian immigrant women living in Portland, Oregon. Bosnia is a society with enduring patriarchal traditions which assume that women are in charge of doing household chores. Men are in charge of providing for the family monetarily. Many Bosnian families migrated to the U.S. in the mid 1990's in order to escape the war in Bosnia. In this study I interview 10 of these Bosnian women, concerning the division of labor in their homes in Bosnia and their homes in U.S. After migrating to the U.S. the amount of work women did within the home lessened as their husbands became more involved in helping with various chores. The changes in the division of household labor did not subvert traditional gender roles. Wives transferred and adapted their views of gender performativity after they migrated to the United States. The results are consistent with research that states that migrant women focus more on advancement of their family rather on their own emancipation.
\end{abstract}




\section{TABLE OF CONTENTS}

$\begin{array}{ll}\text { Abstract } & \mathrm{i}\end{array}$

Chapter 1

Introduction

Chapter2

Literature Review

Division of Household Labor in America $\quad 6$

$\begin{array}{lr}\text { Supermoms } & 9\end{array}$

$\begin{array}{ll}\text { The Gender Revolution } & 10\end{array}$

Division of Labor in Former Yugoslavia $\quad 12$

$\begin{array}{ll}\text { Gender and Immigration } & 15\end{array}$

$\begin{array}{ll}\text { Migration Creating Gender Equality } & 18\end{array}$

The Re-creation of Traditional Roles Post Migration 20

Division of Household Labor in Bosnian Households Post Migration 21

Chapter 3

Methods

Population and Sample $\quad 24$

Research Method 25

$\begin{array}{ll}\text { My Positionality } & 27\end{array}$

Data Collection and Analysis $\quad 28$

$\begin{array}{ll}\text { Gathering Participants } & 29\end{array}$

Setting $\quad 30$

Limitations $\quad 32$

Chapter 4

Findings $\quad 35$

Life in Bosnia $\quad 36$

Women who worked in Bosnia 38

$\begin{array}{ll}\text { What the Men did } & 40\end{array}$

An Equal Division $\quad 42$

Coming to America 43

Division of Household Labor in America 45

Change in Gender Relations $\quad 50$

Comparison with other Bosnian Immigrants $\quad 52$

Comparison with American Households $\quad 53$

Conclusion $\quad 54$

Chapter 5

Discussion and Conclusion $\quad 56$ 
$\begin{array}{ll}\text { References } & 60\end{array}$

Appendix: Interview Questions $\quad 67$ 


\section{List of Tables}

Table 1. Sample Characteristics 


\section{Chapter 1}

\section{Introduction}

Discourses on migrant gender relations, as they exist today in the context of Western interpretations of gender, race, and class, are sometimes not adequate to understand immigrant's interpretations of their own status, rules, needs, and aspirations. Most American feminist scholarship in the field studies migrant's status and role changes in the light of a liberal pluralist world-view. At times the scholarship lacks the historical depth to provide an adequate understanding of their experiences; the questions asked, variables analyzed, arguments developed, and conclusions drawn about refugee and migrant women do not reflect women's experiences and realities (Davis and Sherman Heyl, 1986; Espiritu, 1997; Foner, 1986; Lamphere et al., 1993; Pessar, 1995; Prieto, 1986; Simon and Brettell, 1986). The frequently used triple oppression model of analysisthe status of one subordinated by class, gender, and ethnic minority-implies that the cultural values that these women hold are themselves oppressive. Migrants, based on their own individual historical experiences, may actually choose to continue their traditional forms of living and customs of their home societies rather than adapt to the Western models of living (Franz, 2003; Hirsch, 2003; Pribilsky, 2004). Understanding of migrant's historical, cultural, and socioeconomic experiences and of the immigrant women's own construction of their current lives is necessary in order to fully comprehend their experiences.

Numerous studies have characterized traditional Bosnian families as patriarchal (Erlich, 1976; Franz, 2000; Morokvasic, 1986; Simic, 1999). Women typically prepared and served meals in extended family situations. Many fathers would be disappointed if 
their wife gave birth to a daughter, while boasting the birth of a son (Simic, 1999). Women were in charge of taking care of the home and the children, while the men were responsible for providing monetary support for the family (Erlich, 1976; Franz, 2000; Morokvasic, 1986; Simic, 1999). This traditional view of ‘woman's role' was shifted when Communism came into prominence after World War II (Petkova \& Griffin 1998).

Communism was supposed to change how gender roles are enacted because it would allow women to work outside of the home. Women's emancipation, particularly their heightened participation in production, which should have brought them economic independence and liberation according to communist ideology, consisted in reality of working a 'double day'. As well as a full-time job women had to manage the home, look after their children, and remain socially and politically active (Petkova \& Griffin 1998, Simic, 1999). Lingering patriarchal views required women doing 'men's jobs' to have a feminine touch. One result of this latter view was that many Bosnian women put an astonishing emphasis on looking professional even when coming from their cleaning jobs (Franz, 2003; Petkova \& Griffin, 1998). Thus, women in the labor force in the former Yugoslavia carried the double burden of work in and outside of the home but must also remain feminine and womanly throughout their busy days. This patriarchal tradition was prevalent when the Bosnian war started in the early 1990's.

The war in the former Yugoslavia was characterized by fear, loss and genocide. 97,207 deaths occurred between 1992 and 1997 (Ball, Tabeau \& Verwimp, 2007). Many families fled their homeland because they feared for their lives or lost their homes due to the war (Simic, 1999). These families were not coming to America because they wanted to live the American dream or because they were trying to subvert traditional gender roles 
(Franz, 2000; Simic, 1999). Today there are 98,766 Bosnian people who reside in the United States (Census, 2000).

The purpose of this interview study is to explore Bosnian women's understanding of how immigrating to the United States, and specifically Portland, Oregon, impacted the amount of work that they did within the household and their associated understandings of gender and gender roles. In particular, the research focused on the following questions:

- How do Bosnian immigrant women describe the gender-based division of labor within the household both before and since they immigrated to the United Sates?

- How do Bosnian immigrant women understand the expectations for gender-based division of household labor in other Bosnian immigrant households? In other words, do they see themselves and their household as the same or different as other Bosnian immigrant households in terms of the gender division of household labor?

- How do Bosnian immigrant women understand the expectations for gender-based division of household labor in what they see as the "typical American" household?

- How do these understandings relate to whether Bosnian immigrant women's view of gender roles as either essentialized or socialized and dependent on context?

The aforementioned questions are all related to the Bosnian immigrant women's experiences with household labor in Bosnia and the United States. The questions pertain to different aspects of how Bosnian immigrant women understand their own experience 
as it relates to the division of household labor. Question one allows for a comparison between Bosnian immigrant women living in Portland and their homeland and thus permit inferences about what immigrant scholars label the context of reception and particularly the relationship between women entering the labor market and changes in gender roles.

The second research question allows for Bosnian women to explain if they perceive their experience doing the household chores to be similar to the experience of other Bosnian women living in Portland, Oregon. This allows for the examination if the women in the study perceive the effect of immigration to be a homogeneous one.

The third research question seeks to understand how Bosnian immigrant women living in Portland, Oregon perceive the division of household labor in non-immigrant households. The impact of being a part of the American culture on the division of household labor can be seen here because the respondents, who perceive their experience to be similar to that of Americans, are more likely to be acculturating themselves to American norms.

The fourth question allows Bosnian women to explain how context shaped the degree to which the gender roles they perform are essentialized or socialized. This question allowed for the examination of the perceived impact that American culture had on the gender roles the respondents performed when it comes to the division of household labor.

The research is based on interviews with Bosnian refugee women about the changes within the division household labor after migrating to Portland. I find that a number of assumptions of gender relations in migrant studies did not hold true for 
Bosnian immigrant women in my sample. The potential for emancipation within the household seems to be much less important than incorporating tradition into their new lives in the U.S. I will argue that Bosnian women transfer and adapt their beliefs about gender to the United States. To understand these complexities, it is vital to explore the experience of Bosnian women in the former Yugoslavia and their experience in the U.S. 


\section{Chapter 2}

\section{Literature Review}

\section{Division of Household Labor in America}

In a traditional American middle-class nuclear family household, the husband was expected to go into the labor force and provide the financial capital for the family (Coltrane, 2000; Coverman, 1985; Hoschild, 1989; Thompson and Walker, 1989). He was traditionally the provider and had control of the public domain. The wife was conventionally responsible for the private sphere; she was responsible for doing the household tasks, which included cleaning the house, cooking and raising the children (Berk, 1985; Blair \& Johnson, 1992; Blair and Lichter, 1991; Coleman, 1988; Coverman, 1985; Gershuny and Robinson, 1988, Hoschild, 1989; Thompson and Walker, 1989). The physical, as well as emotional labor the wife provided at home was unpaid. This meant that the wife was traditionally dependent on the husband for financial resources, and ultimately survival.

As time progressed, the traditional nuclear family arrangement began to breakdown. Women started entering the workforce in higher numbers and were more likely to be able to support themselves. In 1984, the United States had 53.6\% of women in the labor market, and by 2009 , that number had grown to $59.2 \%$ (Cotter, Hermsen and England, 2008; US Congress Joint Economic Committee, 2010). Overall, the number of women in the workforce has grown by $44.2 \%$ in the last 25 years; going from 46 million in 1984 to 66 million in 2009 (US Congress Joint Economic Committee, 2010). It was not merely women who were entering the workforce, it was women who had children. In 2008 , the number of working women with a child under the age of 6 was at $64 \%$ and the 
percentage of working women with a child between the ages of 6-17 was at $78 \%$ (US Congress Joint Economic Committee, 2010).

Although the participation of women in the workforce has increased over the last 25 years, it still remains that women continue to receive less pay than men. In 2009, the average full-time wage for women was $80 \%$ of what men received in full- time wage (US Congress Joint Economic Committee, 2010). The fact that women continued to make less money could potentially lead them to remain dependent on their husband for financial resources. The considerably larger wages of men could also be used as a bargaining tool to get out of doing the work within the household. Husbands could make the case that because they make more money, they support the household financially, and that women should support it domestically.

The increased participation of women in the labor force did not create a more equitable division of labor within the household. After finishing their regular work day, many women had to come home and perform all the tasks associated with the second shift (Bielby and Bielby, 1989; Calasanti and Bailey, 1991; Hoschild, 1989; Shelton, 1990). The second shift refers to the unpaid housework that women do after their regular work day is complete. This housework includes making dinner, doing the dishes, cleaning the house, vacuuming and raising the child (Berk, 1985; Coverman and Shelley, 1986; Hiller, 1984; Hood, 1983; Hoschild, 1989; Robinson \& Godbey, 1997; Thompson and Walker, 1989). Doing work both outside and inside the home can be physically and emotionally draining, but many American women were expected to do it. (Gager, 1998 \& Hoschild, 1989). 
Most wives in America do not enjoy doing housework (Gager, 1988; Thompson, 1991). Wives often report negative emotions towards having to do the household work (Gager, 1998); Stress, frustration, exhaustion, depression and boredom are all reported reasons that wives did not enjoy doing housework. In addition to those factors, housework is also something that must be done. It becomes a burden on many American wives and was a reason that many of them do not enjoy doing it (Gager, 1998).

Not only did many American wives report not liking housework, many feel like they can't avoid doing it (Blair and Lichter, 1991; Gager, 1998; Hoschild, 1989; Coleman, 1988). Wives are often in charge of tasks that must be done, such as doing the dishes or cooking the meals. This means that they cannot put off doing household tasks until a later time; they must do them as a part of their daily routine. Husbands, in contrast are often in charge of tasks such as fixing the furniture or changing a light bulb, which are tasks that can frequently be postponed. Husbands can wait until they feel like doing chores, whereas wives often do not have the same luxury (Blair and Lichter, 1991; Coleman, 1988; Gager, 1998; Hoschild, 1989). When husbands do choose to get involved in time-sensitive chores, such as making and packing a lunch for the children, they often feel entitled to stop doing the task at will. Wives however, may feel like they can't just stop doing their chores (Gager, 1998). The second shift still seems to be the wife's primary responsibility, while the husband can chose to get involved and help, but ultimately does not have to.

Husbands are not helping wives within the home at the same rate that wives are entering the workforce. This leaves the wives with a double-burden of working both inside and outside of the home and creates an asymmetry in the change between men's 
and women's employment. The employment of women has increased much more than the employment of men, in fact, the level of employment for men has decreased (England, 2010). There is not one man leaving the labor force to become a full-time homemaker for every woman who entered the labor force (Bianchi, Robinson, and Milkie, 2006). Men also do not pick up household work to the extent that women added hours of employment (Bianchi, Robinson and Milkie; 2006 \& England, 2010).

\section{Supermoms}

Not only are numerous women constantly working, they are also compared to images of "supermoms." Supermoms are the mothers who seem to have everything together and are able to work full-time jobs, take care of their children, their husbands, do volunteer work, have dinner on the table and look very well put-together all the while (Ahmad, 1995; DeMeis \& Perkins, 1996; Hoschild, 1989). This image seems to say that working-women should be able to juggle multiple things throughout the day without needing help (Ahmad, 1995, DeMeis \& Perkins, 1996; Hoschild, 1989; Weingarten, 1978).

When women are not able to juggle the private and public sphere adequately, they are blamed for it in many different ways. First, they are shamed for not being able to be the supermom (DeMeis \& Perkins, $1996 \&$ Hoschild, 1989). If they are incapable of doing all the tasks associated with the supermom role, it is because of their own inadequacies, not because the role is all-encompassing. They are also blamed by being told that they chose to take on the supermom role (DeMeis \& Perkins, 1996; Hoschild, 1989; Weingarten, 1978). The women who chose to go into the workforce and become supermoms could have simply stayed at home and continued taking care of the children. 
The belief is that the wives made the choice to have a career and also be a mother, and if they can't handle fulfilling both roles at once, than they shouldn't have chosen to do both roles in the first place.

In addition to being blamed for their inability to be the master of the public and private sphere, many wives are left with limited choices. Either they can continue to simultaneously work outside of the home or inside of it, or they can choose to retreat back to being the master of the private sphere (Hoschild, 1989). Neither choice allows for them to leave the private sphere completely. They are continuously tied to the work at home. The image of the supermom does not allow for the mom to be more interested in her work. Men on the other hand, are not faced with a similar choice.

While women appear to face the pressure of living to the supermom image, men do not seem to confront similar pressures. Men are still only expected to be the breadwinners in the family (Coltrane, 2000; Hoschild, 1989; Major, 1993). They are not faced with having to work extra hours at home; in fact, when men do help around the house in minimal levels, they are more likely to be praised for it by being identified as a “superdad” (Blair and Lichter, 1991; Hoschild, 1989; Meissner, 1977). Being a "superdad" simply means that men do what is expected and work outside the home and making a contribution to the household labor when they can requires them to be commended for it (Hoschild, $1989 \&$ Meissner, 1977). The status of supermom is expected of working women, but it is not achieved easily. The status of "superdad" is not expected of men, but is more easily achieved. Both statuses, however expect wives to do the majority of the labor within the home.

\section{The Gender Revolution}


The work at home continues to be culturally devalued and it is also one of the reasons that the gender revolution in America has been classified as uneven and stalled (England, 2010). There has been little cultural or institutional change in the devaluation of activities that have been traditionally classified as feminine (England, 2010; England and McClintock, 2009; Hamilton and Armstrong 2009; Sassler and Miller, 2007). As a result, women have had more incentive to move into male dominated arenas, while men have not had the incentive to move into female dominated arenas (England, 2010). The changes in in the gender system show women moving into positions that were traditionally occupied by men such as: managers, doctors and professors while still occupying positions traditionally held by women such as nannies, secretaries, teachers and nurses (England, 2010). Men continue to occupy positions that they traditionally occupied with little change occurring when it comes to occupying positions traditionally held by women (Bianchi, Robinson and Milkie; 2006 \& England, 2010). The reason for this asymmetry is society's value system has not changed; the roles, activities and jobs that are done traditionally by women, such as being a homemaker are generally devalued or not rewarded well (England, 2010; England and McClintock, 2009; Hamilton and Armstrong 2009; Sassler and Miller, 2007).

One of the incentives that women receive for going to work is, of course financial. When American wives enter the workforce it increases the overall earning power of a family. The incentive seems greater for women who have the opportunity to earn more in higher paying managerial jobs which are associated with masculinity (Cotter, 2004; England, Garcia-Beaulieu, Hermsen, Vanneman and Ross, 2004). The jobs associated with femininity, such as a secretary continue to be devalued. The pay for these jobs 
continues to be lower regardless if a man or a woman was performing it (England, 1992; Kilbourne et al. 1994; England, 2010). These economic incentives come from an unchanged devaluation of things that are culturally defined as feminine. When boys take on feminine activities, they are often disrespected or shamed, while under some conditions women gain respect for taking on roles associated with masculinity or roles traditionally done by men (England, 2010). The incentive for men to help out with housework, something associated with femininity, does not seem to be present.

As stated, the gender revolution in America seems to have been uneven and stalled. Uneven because most of the change has been going in one direction; women entering the work force, and stalled because women's employment rates stabilized (Cotter, Hermsen and Vannerman, 2004, 2009).

Many American women have successfully entered the workforce since the midseventies. Once entering the workforce, they were still expected to perform the tasks associated with the second shift. This expectation was exacerbated by the image of the supermom, a woman who can simultaneously work, raise children and take care of the household. Conversely, the incentive for men to enter the private sphere and help with household chores is not present. The incentive for men to do any task associated with femininity is fairly low, especially because those roles tend to be culturally devalued. Devaluing these roles and continuing to expect women to do all the tasks associated with the second shift maintains gender inequality between men and women.

\section{Division of Household Labor in the Former Yugoslavia}

Women's roles in the former Yugoslavia have been difficult to generalize, mainly because former Yugoslavia was a society that exhibited many religious differences, 
ethnic variations and distinct class differences (Franz, 2003). One thing that seemed to be consistent for most former Yugoslavian households was the idea that work life and home life must remain separated, with women being responsible for the home and men for providing the family with money through employment (Morokvasic, 1986). Not only should the differences be maintained, but they must be traditional, which in the former Yugoslavia meant patriarchal (Franz, 2003; Morokvasic, 1986; Simic, 1999). The traditional woman's role was to take care of the children and the household (Simic, 1999). For example, women were responsible for cooking meals and serving them, often to not only their immediate, but also their extended family (Simic, 1999). Women were believed innately to possess qualities such as empathy, caring, and attention to detail, which made them perfect for doing everything associated with the second shift (Franz, 2003; Morokvasic, 1986; Simic, 1999).

Much like in America, Bosnian women in former Yugoslavia started entering the workforce in large numbers throughout the eighties (Petkova and Griffin, 1998). The ideal Communist Bosnian woman of the time was meant to work a 'double-day'. After their work day, Bosnian women were expected to come home and look after the children, the household and remain socially and politically active (Petkova and Griffin, 1998). The prevailing belief was that women who were able to hold down jobs and who were politically active became better mothers to their children (Franz, 2003; Petkova and Griffin, 1998). While American women were dealing with the change in responsibility in the division of labor, their Bosnian counterparts were experiencing similar issues, as they were expected to conform to what an ideal Communist woman was supposed to be. 
The official rhetoric of the time was that women in former Yugoslavia were becoming emancipated by their ability to now work outside of the home (Franz, 2003). However, any emancipation that the women might have felt by getting jobs outside of the home might have been overshadowed by the fact that there was no expectation for men to help within the private sphere (Simic, 1999). It was commonly assumed that women possessed qualities that made them superior for cooking, cleaning and child rearing (Franz, 2003, Simic, 1999). There was not only no incentive for men to help out at home, the overarching belief was that men were incapable of doing most of the tasks at home (Franz, 2003; Simic, 1999). The work that women did at home required a 'feminine touch' that men were incapable of providing. Even when women went into the workforce, they were supposed to exhibit this 'feminine touch.' A result of this idea is that most of women put an enormous emphasis on looking professional when going to work, even if that work did not require a professional appearance (Franz, 2003).

This entrance into the workforce did not change the work that they were expected to do within the home. American women continued doing the majority of the household labor because there was no incentive for their American husbands to help them out. Bosnian women continued to do all of the household labor because it meant that they were upholding the patriarchal traditions of their country (Franz, 2003; Morokvasic, 1986; Simic, 1999).

Unlike their American counterparts, Bosnian women do not report negative feelings when it comes to doing housework (Franz, 2003). A woman being in charge of the household labor is such a prevailing hegemonic ideology, that both men and women seem to believe woman is more skilled when it comes of taking care of the home and 
children. In my opinion, regardless of these differences between the two countries, the division of household labor is the one place in which the gendered revolution is continuously uneven and stalled in both Bosnia and the former Yugoslavia.

\section{Gender and Immigration}

Gender is a force that influences migration and the lives of migrants (Mahler and Pessar, 2006). Despite this fact, gender has often been overlooked in scholarly research on international migration (Mahler and Pessar, 2006). Most research on migration has focused on 'sex'. Sex however is only a dichotomous variable that distinguishes male from female. Gender is far more multifaceted as it involves the way cultures infuse the biological difference with meanings distinguishing between male and female domains in activities, tasks and spaces (Mahler and Pessar, 2006). Gender must be used in order to understand the changing experiences of groups post migration.

Although gender has not always been represented in scholarly immigration research, it does not mean that women have migrated across international borders any less then man. In fact, women migrate across international borders at about the same rate as their male counterparts (DeLaet, 1999). This migration trend did not translate into research attention until the 1980's when women's experience became a higher priority in migratory research (Mahler and Pessar, 2006; Morokvasic, 1984; Ong, 1991). One of the focuses of this research became how men and women organize their time as it relates to the division of labor in a new setting (Eastmond, 1993; Gamburd, 2000; Hirsch, 1999 Kibria, 1993; Morokvasic, 1984; Ong, 1991; Pessar, 1986 Hondagneu-Sotelo, 1994; Ui, 1991). 
Upon migrating to another country women have the opportunity to question the hegemonic notions of gender (Pessar and Mahler, 2003). They are able to understand gendered lives in a new way. Many immigrants begin questioning the existing male/public and female/private domains that they held in their country of origin (Pessar, 2001). This questioning often coincides with a newfound freedom experienced once women find employment (Pessar, 2001: \& Ong, 1993)

When men are the only people to migrate from their country of origin, they are more likely to internalize the gender norms of the new culture and be more open to sharing in household tasks (Mahler and Pessar, 2006). Conversely, when families migrate together men expect their wives to adhere to traditional gender norms and do the work within the home regardless of the wife's employment status (Hondagneu-Sotelo, 1994; Ong, 1993). More often than not, when a family migrates together the men will try to preserve gender norms from their country of origin as a way to buffer the stress associated with migration and acculturation (Hondagneu-Sotelo, 1994; Ong, 1993). For example, some Ecuadorian men do not allow their wives to speak about their new lives to their families back home. The wife's newfound freedom in the arena of work is mitigated by the husband when it comes to the work done at home (Kyle, 2000). In order to preserve tradition the wife is often expected to perform most if not all household duties (Ong, 1991; Pessar, 1986 Hondagneu-Sotelo, 1994; Ui, 1991)

Men may also want their wives to adhere to traditional gender norms. Men are less likely to create household strategies that are consistent with long-term resettlement (Hagan, 1994; Kibria; 1992, Rouse, 1992). Men often think that the resettlement is not permanent and they anticipate going back to their home country eventually. Men become 
more committed and are more invested in maintaining transnational ties with relatives and friends from their home country (Jones-Correa, 1998 \& Goldring, 2001). One reason for this is that men want to maintain transnational ties in order to facilitate a quicker return to their country of origin and to position themselves within arenas of male privilege in male-headed transnational community associations (Jones-Correa, 1998; Goldring, 2001; Mahler and Pessar, 2006;). Many men also become nostalgic about the positions of power or privilege that they held in their home country and are then more likely to reminisce about 'the way things used to be' (Franz, 2003; Goldring, 2001; Mahler and Pessar, 2006).

Much like men, women also maintain transnational ties by communicating and sending money to their friends and families in their country of origin (Franz, 2003 \& Pessar, 1986). However, many women from distinct nationalities and differing host countries are more likely to seek and maintain personal relationships and gains obtained in the country that they migrated to (Chavez, 1992; Franz; 2003; Pessar, 1986). This is one way that women can ensure that their stay in the country that they migrated to can be prolonged. Women also seem more willing to create closer social bonds in the new country of origin as a way to ensure that the family can prosper (Franz, 2003). This is one of the reasons that women often feel that their social status improves post migration, whereas men feel that theirs does not (Hagan, 1994; Kibria; 1992, Rouse, 1992)

After migration women are more likely to find employment. This leads them to experience gains in personal autonomy and independence, whereas men feel like they are losing ground. This is particularly true for households in which women make more money than men (Eastmond, 1993; Gamburd, 2000; Hirsch, 1999 Kibria, 1993; Pessar, 
1986; Ui, 1991). Some women are able to use their greater earnings as leverage to bargain for grater equality within the household (Pessar, 2006). They can bargain for more help with childcare, housekeeping, budgeting and allocation of the family's funds. Higher income for women enables them to negotiate for greater equality within the household and leads them to create more equitable spousal relationships (Hirsch, 2003; Pribilsky, 2004).

Migration Creating Greater Equality

An example of women using new found freedoms to negotiate for more equitable spousal relationships can be seen in the case of the Chilean families who were exiled by the Chilean government and moved to the United States in the 1970's (Eastmond, 1993). These women were primarily middle class Chilean wives who were responsible for child rearing and taking care of the home. If the husbands were away, the wives were also responsible for taking care of the farm with the help of the husband's male relatives, usually brothers (Eastmond, 1993).

After their exile, Chilean refugees arrived to the United States, a place which was foreign to them, offered little monetary assistance and had historically been considered an enemy of their country of origin (Eastmond, 1993). One way that the Chileans coped with this exile was to try to recreate old, familiar traditions. Language, forms of address, food and clothing which were normally not reflected upon became conscious symbols and values associated with being Chilean (Eastmond, 1993). A tradition that was recreated upon arrival was the dividing of the household labor, and leaving the women in charge of household duties such as meal preparation (Eastmond, 1993). 
While the migrants tried to recreate old traditions at home, finding work became a struggle. In order to survive both the spouses had to find employment. Working outside the home was new for most of the Chilean women (Eastmond, 1993). Because many had migrated to northern California, finding jobs at the Silicon Valley was not difficult. The ability women to find and keep jobs played a big role in garnering self-confidence and obtaining domestic authority (Eastmond, 1993).

The new work patterns between the spouses affected role performances within the household. The work roles in Chile tended to be very complementary between husbands and wives; however the work roles in the United States became more interchangeable (Eastmond, 1993). As wives started going to work in greater numbers, the husbands had to help out within the home. The society around them also provided an alternative model of gender relations which the wives internalized used it to negotiate for greater help within the household (Eastmond, 1993). The differing social position of men and women which was taken for granted in their country of origin became more obvious after migrating and was used to create more equitable relations when it came to the division of labor within the household (Eastmond, 1993).

Changing gender roles due to migration does not always create positive relationships between spouses. In some situations, increased autonomy of the wife creates dramatic tension within the home and men attempt to regain control by emotionally and physically abusing their wives (Abdulrahim, 1993; Pena, 1991). In some Asian Indian and Cuban households women are expected to keep with tradition and do all the household tasks, regardless of if they have a well-paying job or not (Mehrotra, 2010; Vidal de Haymes, 1992). Women in turn comply with doing most of the household labor 
as a way to make sure that their family remains together and that their husbands do not feel emasculated (West and Zimmerman, 1987)

\section{The Re-creation of Traditional Roles Post Migration}

An example of women not being able to use new found freedoms to negotiate for a more equitable division of household labor can be seen in the case of Asian Indians who migrated to the United States (Bhalla, 2008). Traditional family life in India divides men and women into two spheres. The men occupy the public sphere by holding a job outside of the home and being the sole breadwinner of the family. Women occupy the private sphere by doing all of the work within the home which includes; cooking, cleaning and child rearing. Cultural norms prohibit many women from acquiring jobs outside of their home (Bhalla, 2008).

Once the Indian couples migrate to the United States women take on additional responsibilities by obtaining jobs outside of the home. Their newfound autonomy does not translate into fewer responsibilities within the home (Bhalla, 2008). The husbands expect the wives to fulfill their traditional duties within the home in addition to doing all the work within their household.

The husbands do not take on additional responsibilities within the home regardless of their employment status. If they are able to find employment, they work outside of the home. If they do not find employment they contribute very little to the housework that needs to be completed (Bhalla, 2008). When wives complain about the amount of work they do and try to bargain with their husbands the situation does not improve still. The loss of status seems to be a main reason that the Asian Indian husbands choose not to help their wives with child rearing and household duties (Bhalla, 2008). 
Wives take on the double burden of working within and outside of the home in an effort to preserve traditional values and not emasculate their husbands. In the case of the Asian Indians maintaining traditional gender roles after migrating to the United States seems to be more important than changing them.

In short, the above cited literature indicates that after migrating some groups seem to create relationships in their new place of origin that foster a more equal division of household labor while others do not.

\section{Division of Household Labor in Bosnian Households Post Migration}

The research that deals with division of household labor with Bosnian women has been scarce. There is however some data that examines the impact of changing gender roles on Bosnian families that immigrated to New York during the Bosnian war of the early to mid-nineties. The profile of the Bosnian groups that had resettled in New York was remarkably homogeneous. Most had come with their immediate family; most had classified themselves as belonging to the middle class, and holding professional jobs in their country of origin (Franz, 2002). The majority of the immigrant Bosnian women in New York also reported working in their country of origin, and this was true regardless of age, marital and socioeconomic status. After arriving in the New York, Bosnian refugees were in a position to take advantage of many resettlement programs (Franz, 2002). The resettlement programs were based on an assumption that most of the refugees coming from Bosnia would be interested in staying in New York, permanently. They also worked under an assumption that economic self-sufficiency through employment was necessary for permanent residence. The resettlement programs provided incoming immigrants with basic English as a Second Language (ESL) education; early assistance finding 
employment (usually minimum wage); assistance finding housing and assistance obtaining finances for food and clothing (Franz, 2002). This meant that most of the Bosnian immigrants and refugees coming into the United States in the mid-nineties had immediate access to the job market and to public assistance (Franz, 2002 \& Franz, 2003). Another privilege that Bosnian immigrants enjoyed in the United States was that they were encouraged to become citizens after five years of residence (Franz, 2003). This form of potential security freed many immigrants from feeling pressure and stress and allowed them to focus on starting their new lives in America instead (Franz, 2003).

Both men and women who resettled in New York between 1993 and1999 were able to find employment quickly. Men were likely to find jobs in construction and women were often cleaning ladies (Franz, 2003). Although both men and women were able to find jobs outside of the home, the work within the home continued to be divided, mainly due to the differences in self-perception of Bosnian men and women.

Bosnian men were resistant to changing their gender roles after migrating while the women remained focused on providing for their families financially and emotionally (Franz, 2003). Bosnian women focused on raising their children, helping with the children's education, finding bigger, more comfortable apartments and keeping the family generally happy (Franz, 2000). Keeping the family happy and basing their identity through familial interactions often meant adhering to Bosnian gender roles (Franz, 2000 and 2003). This meant that most women continued being the ones responsible for preparing and serving meals, cleaning the home and raising the children (Franz, 2000 \& Franz 2003). The value of familial ties among Bosnians is also supported in studies by 
Bell (2001) and Sossou (2008) in which Bosnian women claimed that family was what kept them alive through the war and their refugee and immigrant experiences. .

Another factor that contributed to women adhering to traditional gender roles was the inability of the men to assimilate. The men seemed to hold on to their previous ethnic and status identity (Franz, 2000). The identity of the Bosnian men seemed to be tied to their places of origin, and their economic standing within the communities of their places of origin (Franz, $2000 \&$ Franz, 2003). Holding on to their previous identities often meant that they expected their wives to hold on to the identities that they had previously had. In effect, this means that many men wanted their wives to adhere to traditional gender roles and to continue being responsible for the household labor (Franz, 2003).

If Bosnian immigrant women construct their identities in a new country by holding on to traditional forms of life, the expectation would be that they will perform the same roles that they had in their country of origin. This study will examine how Bosnian women describe the division of household labor in their country of origin and in the United States. If the subjects perform roles in the United States similar to the ones they performed in Bosnia, then this research will support the findings of previous studies done on this topic area. If the women perform roles differently when it comes to the division of household labor, then it will give additional insight into how Bosnian women have constructed their identities in Portland, Oregon post migration and their processes of assimilation and integration. 


\section{Chapter 3}

\section{Methods}

\section{Population and Sample}

The population selected for this study was Bosnian women who lived in Bosnia prior to the war, had been married, had children while they were in Bosnia, and moved to the United States between 1992 and 1999. These years were chosen because they correspond to the time of the Bosnian war and the greatest out-migration from Bosnia (Franz, 2003). The sample was limited to women who migrated with their husbands and children and are currently living in Portland, Oregon with their husbands. All the women in the sample had children in Bosnia and migrated with those children. Three participants had one child and the other participants had two children. Of the 17 children, two were born in the United States. All of the participants in this study currently have a job outside the home. One participant works two jobs. Seven out of the 10 participants had a job outside of the home while they resided in Bosnia. By examining the experiences of Bosnian women who are living in a very similar household configuration here as they were in Bosnia enabled a direct comparison between their lives in Bosnia and Portland.

All the participants who were selected were born in Bosnia, and they all lived in southwest Portland. Although they lived in the same area of town, none of the participants formed immigrant neighborhoods in which they could communicate with one another on a daily basis. The participants felt generally isolated from other Bosnians. The majority of the participants arrived to the United States in 1997 or 1998 and immediately settled in Portland. All of the participants are currently married to the same man to whom they were married while they were living in Bosnia. Only one participant was married 
more than once. This first marriage ended in divorce in Bosnia and produced no children. Most of the participants were in their forties when they arrived in the United States. The youngest participant was 23 when she arrived to the United States and the oldest participant was 59when she arrived. All participants said that they could speak some English, they however preferred to speak in Bosnian during the interview, and three mentioned that they could speak English fluently.

Two of the participants have offspring who currently live with them. The youngest of these is a 14 year old high school student who lives with the youngest participant in the study. The majority of the children have moved out of their parent's home after their arrival to the United States.

The majority of the participants arrived to the United States as immigrants. They either had relatives here who helped them, or they applied to come here through various organizations. One of the participants arrived through an organization, but also had an individual sponsor who helped her financially. Six of the ten participants did spend some time in another country before arriving to the United States. Many were refugees in countries close to Bosnia, such as Croatia, Montenegro and Serbia.

This study utilized a convenience sample. Participants were chosen through personal contacts and community gatherings which were easily accessible by the researcher. Because the participants were recommended to the researcher through mutual contacts, the likelihood of participation was increased.

Research Method

The qualitative method was used in this study as it focuses on the lived experience of the subjects being studied (Marshall \& Rossman, 2010). This research strategy was 
employed because it deals with issues that have previously not been addressed with this particular population in this setting. There are no secondary datasets that address the division of household labor amongst Bosnian immigrant women. Using a qualitative method helps uncover the unique issues that this immigration population of Bosnian women faced in the division of household labor.

This approach was also appropriate because to understand the lived experience of my subjects I need to understand these experiences from their perspectives. This study also focused on the context surrounding the subjects' lived experience. In order to understand the impact of the context on Bosnian immigrant women's experiences, it is imperative that these women shared their own understandings of the influence of this context. Studying the lived experience and the context of that lived experience to construct a narrative of the lives of the participants lends itself to the interview technique utilized in qualitative research (Marshall \& Rossman, 2010). An additional reason for using a qualitative study to examine this population was that a quantitative study would use a coding system that would have invariably stifle the array of experiences my subjects shared with me. (Marshall \& Rossman, 2010)

Of the varying techniques of interviewing, this study utilized semi-structured ethnographic interviews as the sole technique for gathering data. Semi-structured interviews were uniquely suited for this study because they allowed the researcher to follow pre-determined themes, but also allowed for probes and follow up questions that arose after the participants answered the initial question (Berg, 2009). Of primary importance was addressing the phenomenon at hand from the participant's perspective, the emic perspective (Marshall \& Rossman, 2010). 
Another advantage of this method is that it focuses on the construction of culture from the participants' point of view and it elicited the participants' meaning of behaviors and events (Marshall \& Rossman, 2010). Using ethnographic semi-structured interviews allowed me to gauge what the participants' perception of the division of labor within the home was in America and Bosnia which was crucial in answering my research questions. An additional strength of this method was my ability to observe social cues of the participants such as voice, intonation and body language. The evaluation of verbal responses ad observable social cues was utilized to answer to answer my research question.

My Positionality

I am a Bosnian-born male who emigrated from Bosnia with my mother when I was six years old in 1992. We left because of the war that was going on in Bosnia in the early 1990's. We first went to the Czech Republic where we lived as refugees for five years. We lived with about a hundred other people, all of whom were women and children. We moved to the United States in 1997, after being sponsored by an organization that helped immigrants resettle. My experiences have given me some knowledge about how gender roles are expressed in Bosnia and how they are expressed by Bosnian people after they migrate to the United States. In my own family all women took care of the household and all of them also worked outside of the home.

Growing up in Bosnia gave me insight into how gender roles are expressed both prior to and after migration. I observed that in Bosnian women were in charge of the domestic sphere, even though many typically worked outside the home. I knew that during my interviews most first generation Bosnian women would be more comfortable 
speaking in Bosnian. I was aware that many Bosnian women would not be comfortable addressing certain topics such as the war; I was however confident that they would not mind discussing gender roles pre and post migration. My insight however is limited because it is purely based on personal observations and because I had never systematically asked anyone about the division of household labor.

\section{Data Collection and Analysis}

The researcher was the primary instrument for collecting and analyzing data in this study. I conducted open-coding (Strauss \& Corbin, 1998) of the interview transcripts. This consists of reading the transcriptions of the interviews multiple times in order to familiarize myself with my data. I highlighted salient quotes and examined the similarities and differences in the experiences that my subjects had. I noted the reoccurring ideas, concepts and opinions. The ideas and concepts that were not reinforced were also compiled as they could be used as effective counter examples to the dominant themes that emerged. The next step was to conduct axial coding (Charmaz, 2006; Strauss \& Corbin, 1998) where the connections between categories and subcategories are made in an effort to solidify the major concepts. When key concepts emerged, common concepts were identified and themes emerged. When similar categories were combined, the dominant themes emerged.

Because the interviews were done in Bosnian, the coding and the definition of themes were done from the Bosnian-language transcripts. Relevant quotes and passages were translated into the English language so that the main themes could be disseminated to a more broad audience. The passages were translated by the primary researcher, but were checked by two additional translators. 


\section{Gathering Participants}

The initial batch of participants was gathered through the researcher's participation in after church activities. I went to the Serbian Orthodox Church in Milwaukie with a family friend in mid-July. While there, I was invited to attend an after church barbecue. While at the barbecue I approached potential participants of my study. I informed the potential participants about the nature of the study. I told some potential participants I would be interested in speaking with them about how they divide household labor, and how they divided it in Bosnia. I emphasized the fact that this was something I was doing for school and that if they agreed to an interview it would not contain any questions about the war in Bosnia. I was fearful that if the participants felt like they would have to answer questions about the war, they would not be interested in participating in the interview. I also assured my potential participants that I would not disclose any information they did not feel comfortable with me disclosing.

The women who showed interest in participating in the study were asked some screening questions. They were asked to verify that they were born in Bosnia and they were married there. The participants also had to verify that they immigrated to the United States sometime in the mid-nineties. The participants had to also state that they are currently married or cohabitating with a partner. Once deemed eligible I asked for my participant's phone numbers so that I could contact them for an interview. A total of five participants were gathered from the church.

The other five participants were gathered through personal contacts.. I spoke to family friends and told them about the nature of my study. I asked them if they knew any women who would be potentially interested in taking part in my study. They 
recommended some women to me, and I called them to set up interviews. Although five participants were gathered through personal contacts, I made sure that I did not know any of the participants. By gathering participants through personal contacts I was assured that I would get a more diverse sample than those from a single church. Had I only recruited from the church I might have ended up with a sample of women who were too similar. Certainly, all the women from the church would all be the same religion.

All of the participants were born in Bosnia. Eight of the participants lived in Bosnia up until the start of the war. One participant moved to Serbia, one to Croatia and one to Montenegro. Six of the participants lived as refugees in other countries before immigrating to America. The length of time lived in these countries ranged from three months to two years. The participants were between 38 and 70 years old with most of them being in their late forties and early fifties.

\section{Setting}

All ten of the interviews were conducted in the homes of the participants. This was because the researcher felt like it was important to conduct the interviews in a setting in which the participants would feel most comfortable. When I set up a meeting, all participants were asked if they would rather meet in a public setting, and all of them preferred to meet in their homes.

All interviews were conducted during the summer, specifically, July and August of 2012. All the interviews were conducted in the evening after 7 p.m. or in the morning prior to 11 a.m. This was due to the fact that all of the participants in the study either worked nights or mornings, so the interviews were always scheduled around their work 
hours. None of the interviews needed to be re-scheduled. Each participant notified me of a good time to meet them, and complied with the time they set up.

Prior to the start of the interviews I went over the consent form with the participants. Each one agreed to sign it, and each participant felt comfortable to let me use their first names in my final paper, and any ensuing publications. I also told the interviewees that none of the questions would pertain to any war traumas that may have occurred, and that if they felt that interview was invasive at any point they can ask to stop it and can choose to no answers a particular question. No interviewee ever stopped an interview and no questions were ever skipped.

All interviews were conducted in private, and only I and the participant were present for them. One participant had her son at home when I arrived, and asked if it was okay if her son was present for the interview. I told her that I would prefer for the interview to be done in private, so she asked me to stay at her home until her son went to work, which was approximately thirty minutes after I had arrived.

I adhered to the interview script during each of the interviews but also utilized probes and asked for clarification when it was necessary. As I was the primary instrument for gathering and analyzing data in the study, it was important for me to be open and friendly when speaking with the participants. I asked them about their day and chatted with them about their work and about my studies before initiating the interview. Prior to the start of the interview, I asked the participants to give verbal consent to be audio recorded. They were asked this, even when the consent form also explicitly states that they are going to be audio recorded. I wanted to make sure I had a verbal and written consent to go ahead with the interviews. 
Another interesting thing that happened during many interviews was the importance that the participants placed on hosting me. Three of the participants had made lunch prior to my arrival and wanted to lunch with me prior to the interview being conducted. Two additional participants had made snacks. Most of the participants asked me where I would feel most comfortable conducting the interviews, which normally was the dining or living room. One of the women in the study asked me to stay at her home after the interview, so we could continue our discussion, and she showed me her daughter's wedding video. After watching the video she sent me home with food that she had prepared. There was definitely a sense that these women felt it was very important to be good hosts to me.

Each interview was recorded using a digital audio recorder. The average interview lasted from twenty-five to thirty minutes with the shortest interview being twenty minutes and the longest being forty-two minutes. I transcribed all the interviews verbatim in order to prepare them for analysis.

\section{Limitations}

A weakness of this study could be the level of openness the subjects might have with me because I am a male. This trust could become an even bigger issue if the respondents suffered traumatic events during the war at the hands of other men. One thing that will increase their trust is the fact that I am also a Bosnian and that even though I am a male I was very young at the time of any of the trauma that they might have experienced. My ability to converse with them in their native tongue should also decrease potential mistrust. The fact that the interview questions were not about the war may also make the participants more comfortable. 
An additional limitation is that my results will not be generalizable to all Bosnian immigrant women. There could be something about Portland, Oregon that makes the experience of the Bosnian immigrant women living here unique and different from Bosnian immigrant women living elsewhere. Perhaps the context of reception in Portland is friendlier than in areas of the country that have a turbulent relationship with incoming immigrants. Although the study will not be transferable, it may be representative of the population of Bosnian immigrant women living here. The subjects of this research are women. Accordingly, this research cannot address how Bosnian men perceive and understand gender roles and the changes that living in the U.S. might have produced. Another limitation could be the fact that I was born in Bosnia. I may have biases because I am a part of the Bosnian culture and this may cause me to anticipate certain responses from the participants. I have spent most of my life in America. I speak English fluently and have received most of my schooling in the United States. I am enrolled in a Master's program which comes with a certain educational privilege that could be a potential limitation and must be accounted for.

The voices of men are excluded from this study which is an additional limitation. Husbands may have a different view on how the division of household labor is divided and why it is divided the way it is. Their opinions and experiences are excluded because they are not the subjects of this study. 
Table 1: Sample Characteristics

\begin{tabular}{|c|c|c|c|c|}
\hline $\begin{array}{c}\text { Participant (In } \\
\text { Order of } \\
\text { Interview) }\end{array}$ & $\begin{array}{c}\text { Name } \\
\text { (Pseudonym) }\end{array}$ & $\begin{array}{c}\text { Age } \\
\text { at time of } \\
\text { interview }\end{array}$ & $\begin{array}{c}\text { Arrival Year in } \\
\text { USA }\end{array}$ & $\begin{array}{c}\text { Worked in } \\
\text { Bosnia }\end{array}$ \\
\hline Participant 1 & Velinka & 63 & 1997 & Yes \\
\hline Participant 2 & Seka & 54 & 1994 & Yes \\
\hline Participant 3 & Magda & 38 & 1997 & No \\
\hline Participant 4 & Jadranka & 50 & 1998 & Yes \\
\hline Participant 5 & Stana & 55 & 1998 & No \\
\hline Participant 6 & Malina & 63 & 1999 & Yes \\
\hline Participant 7 & Slavica & 46 & 1995 & Yes \\
\hline Participant 8 & Zorica & 70 & 1999 & Yes \\
\hline Participant 9 & Branka & 41 & 1999 & No \\
\hline Participant & Desa & 54 & 1997 & Yes \\
\hline
\end{tabular}




\section{Chapter 4}

\section{Findings}

Consistent with prior research on gender roles pertaining to the division of household labor (Franz, 2000 \& 2003), this study finds that Bosnian women were responsible for doing the vast majority of the household chores while living in Bosnia. Regardless of their work status women were often responsible for meal preparations, doing the dishes, washing the clothes, ironing the clothes, cleaning the bathrooms, dusting, grocery shopping, and the majority of child rearing. Men were expected to provide monetarily for the family. The household chores that men were responsible for were the ones deemed more physically demanding and chores that were not time sensitive including; fixing household appliances, mowing the lawn, general home maintenance, paying the bills. Men were also involved in the rearing of their children; however the degree of their involvement was lesser than that of their wives.

After migrating with their families to the United States, the division of household labor changed for the couples. Men became more involved in helping their wives with various chores around the household, which is consistent with some previous research on gender and migration (Eastmond, 1993; Hirsch, 2003; Pessar, 2006; Pribilsky, 2004). The instant need to establish a life in a foreign country, provide for their families, and be financially stable were reasons for women getting jobs outside of the home and requiring their husbands for increased help within the home. Men's involvement with their children, their participation in meal making and doing the laundry increased.

Although men's participation in household chores increased, the maintenance of gender roles remained clear in every household. Each wife was assigned a particular role 
within the household that was inflexible. That is to say, she had to perform this role regardless of her job status or time availability. In some households this meant that a wife was always responsible for cooking the meals, and in others it meant she always did the dishes. Husbands did more of the household labor once the families migrated to the United States. This however did not reflect subversion of gender roles. Gender roles remained clearly distinct and were changed only slightly because of the stress associated with the couples working in America.

In the following section I will discuss how the participants divided household labor in Bosnia. The amount of the household chores done by women who had jobs outside of the home and the amount of chores done by men will be examined in the subsequent sections. A couple that divided household labor equally in Bosnia, and the reasons for this equality will be discussed after this. I will then discuss how coming to the U.S. impacted the division of household labor. After this I will discuss how the participants understand the way they divide household labor as being similar or different from other Bosnian families living in Portland and from American families.

\section{Life in Bosnia}

When women who were interviewed had been living in Bosnia, they were expected to adhere to traditional Bosnian gender norms. This meant that they were in charge of running the household. They prepared meals, cleaned the house, decided what groceries were to be bought, washed the dishes, did the laundry and ironed clothes. Nine out of 10 participants spoke about not expecting their husband to help with any chores that needed to be done while in Bosnia. Stana, one of the participants took pride in being a housewife and saw it as her natural role: 
"Everyone knows what they need to be doing. I was the homemaker; I cleaned, cleaned after people. My husband was at work, if we needed firewood than he was responsible for getting it and doing those more difficult manly jobs. I did all the work at home. I was the cook, I did the cleaning, I did the dishes....I did everything. I was happy to; I think that over there (in Bosnia) that was normal."

Being responsible for household chores was not something Stana saw as a burden. She was happy to do all of the chores within the household and did not question her role as a homemaker. She in fact, normalized the role by explaining that this was something that was expected of women to do and it was natural that women were doing it.

A majority women in this study indicated that taking care of the household was their responsibility because they were raised by their own parents to hold this view. All of the participants in the study indicated that they had seen their own mothers do household work. In some cases the mothers of the participants took on an instructor role and taught their daughters how to cook and clean properly. Additionally, some women felt that the men were not being taught about doing household chores at all. This lack of knowledge on the men's part was used as a reason as to why the household duties fell on the shoulders of the women:

"Cooking was back then, is now and will always be my responsibility. He could maybe heat up some soup or boil some water, but he is in no way a cook, but that's because he was not raised to be a cook. We were raised by a generation of people that were traditional and lived in a place that was traditional. Men don't cook, men don't clean. He didn't help me at home not because he did not want to, but because he was not raised to know how to help me. He didn't know how to cook, so he didn't cook. I 
made our meals and if I didn't all he would ever eat would be french fries."

Desa, the woman quoted above, invokes the idea that years of tradition in how children are raised played a large role in normalizing the idea that women are more capable in doing household chores. This normalization in turn made it seem that it was natural for women to be housewives.

\section{Women Who Worked in Bosnia}

Out of the 10 women interviewed, three were housewives in a traditional sense. This means that they took care of the home and did not have jobs outside of the home. The rest of the women interviewed all had jobs outside of the home that they deemed necessary for the survival of their families. All seven of these women also stated that if they had the opportunity to stay at home in Bosnia and be a housewife, they would have chosen not to do so. Work was an integral and important aspect of their daily lives that seems to have been necessary for the survival of the household and for personal fulfillment as one of the participants Jadranka describes:

"I would always work. I couldn't do that....that sitting around at home all day just to bore myself all day. Having a job is always necessary if you want to have a good life and if you want to earn a lot of money. So, you can't live without working. If you want your family to survive and you want them to have a good life than you have to work."

Jadranka chose to work because she did not find housework to be a fulfilling experience. She thought that she would be bored and dissatisfied with her life if she was only identified as a housewife. She also chose to work because it meant she could provide a 
better life for her family. The money she brought into the household in conjunction with the money her husband would bring provided them with a more stable life, because with two paychecks they were able to pay all the bills and save money for future expenses. The sentiment expressed by Jadranka was similar to the one expressed by the other six women who held jobs outside of the home.

An assumption could be made that because many of the women in this study worked outside the home it would mean that the responsibilities that they had within the home would lessen. However women who held jobs were doing the vast majority of work at home. Jadranka, the woman who felt the need to have a job outside of the home in an effort to avoid boredom also expressed that she was still working once she came back from work, which is consistent with the idea of the second shift (Hochschild, 1989):

"I did the majority of work at home (In Bosnia). This means I cooked the lunch, and every other meal and snack and anything else. I did the laundry, I ironed it, and I cleaned the floors, the bathrooms, and everything else....what else is there. I was responsible for the household work. I worried about the kids, about what they would wear, what they needed to be bought for them, I raised them as they grew up, I helped them with their homework, but we did all take trips as a family."

Jadranka emphasized that no matter what her role outside the home, her role within it stayed traditional. She talked about raising the children and making sure that they had the basic necessities such as clothing. In an effort to show that her husband was involved in their children's lives she points out that he was present during family vacations. She also mentioned that her husband was involved in the children's lives when it came time to take 
them to the zoo or on various other trips around the city. The disciplining of the children was hers alone.

The wife's role in the traditional Bosnian household was that of caretaker. She was the one responsible of taking care of the house and the family. This was true whether she worked outside of the home or not. This idea is supported by additional sources (Franz, 2003; Morokvasic, 1986; Simic, 1999) which identified he traditional Bosnian woman's role was to take care of the children and the household.

\section{What the Men Did}

Although the women performed the vast majority of the household jobs, the men did chores that were more physically demanding that could be done at the husband's leisure. The physically demanding chores included: moving the furniture, fixing household appliances, and washing the car. Chores that could be done at the husband's leisure included: paying the bills or changing the light bulbs. Zorica, a woman who held a job as a cashier at a store, explained why her husband was in charge of paying the bills:

"I only handled paying the bills when he was away in Iraq on business. When he came back of course, I mean he has a man's brain. Who else is going to do it? He took care of all the bills. He is going to pay all the bills and he is going to keep track of everything we paid and he is going to have the evidence of the fact that we paid it. He has to do it all; he has the man's brain for all those sorts of things."

Zorica talks about the division of household labor in gendered terms. Just as Stana assumed that women are naturally predisposed to staying at home, Zorica assumes that 
men, by nature have the brain for paying the bills and keeping track of what bills were paid. The idea that men are better at doing certain chores is shared by Jadranka:

"He did all the male jobs around the home. This means he fixed things if they were broken; he went on the roof to fix it if he needed to, he mowed the lawn, and he bought the furniture and carried it back home. He was responsible for doing those types of things that were a bit harder to do, I mean I would check on him to see if he was doing things correctly, but he was really responsible for all the male jobs around the house."

Gender is used to explain what jobs were done by men and what jobs were done by women. Jadranka is saying that within the household there are such things as male jobs. Her husband is predisposed to do these jobs and she is not. The jobs that he does are however defined by their physicality in nature and by the fact that they don't have to be done daily. Her husband does not have to fix the roof or buy furniture every day of the week. The grass is not mowed every day; during the winter it is not mowed at all. He has flexibility when it comes to choosing the appropriate time to do the chores assigned to him. The jobs that women do within the household are done daily such as meal preparation, or several times a week such as doing the laundry.

The way that the participants divided the household division of labor is in line with previous research that suggests that men take on tasks that can be avoided or do not have to be completed at a set time (Blair and Lichter, 1991; Gager, 1998; Hoschild, 1989; Meissner, 1977; Coleman, 1988). Women are in charge of tasks that must be accomplished by a certain time and make it a part of their daily routine (Blair and Lichter, 1991; Gager, 1998; Hoschild, 1989; Meissner, 1977; Coleman, 1988). In Bosnia 
this division is crystallized by the idea that women are inherently better and naturally predisposed to take care of the home (Bell, 2001; Franz, 2000 \& 2003; Morokvasic, 1986; Simic, 1999; Sossou, 2008)

\section{An Equal Division}

In nine out of the 10 interviews the division of household labor was divided in such a way that women did the vast majority of the work. The division was not equal in any of the households except one. Malina lived in a small rural Bosnian city called Konjice. She was her husband's second wife. They had one child together and, he had two children from his previous marriage. One of the children from her husband's first marriage was intellectually disabled and required extra attention from both of them.

Their household also included his parents, who were both elderly. The husband's mother was bed ridden and required care.

Malina worked in a factory during the day and her husband worked in the same factory during the night shift. They split up their work schedule so that someone could always be at home in order to take care of the household:

"He did the chores when I was at work in the mornings. If he worked in the mornings, than I did the chores. In this way we were helping each other. We had to fill in for each other when it was necessary. I didn't have it easy with having to work and finding myself in a house with two kids that were not mine and taking care of my mother in law. For an example: if I go to work in the mornings than he has to make the lunch for the family, he has to clean and take care of his mom. On my way back from work I pick up the kids from school and make dinner for everyone. Everything else gets done in the meantime." 
Malina was the only participant who divided the household labor between herself and her husband equally, while living in Bosnia. Although there was equality in household labor, it is not clear if it existed because they believed that dividing the household labor this way was the right thing to do or because circumstances forced them to create equality. Malina calls attention to their living situation as a contributing factor for the created parity. If her husband did not make meals, not only would he not be fed, but neither would his parents or children who lived within the household. No matter what the reasons, the division of household labor within Malina's home was different from any of the other women. She and her husband helped each other in chores ranging from washing the dishes to paying the bills. The relationship that they had is unique especially because previous literature about the division of household labor in Bosnia assumes that women do the vast majority of the work (Bell, 2001; Franz, 2000 \& 2003; Morokvasic, 1986; Simic, 1999; Sossou, 2008).

\section{Coming to America}

The need to provide for the family and the desire to create a better life for their children was a central theme that all the participants. Desa took on two jobs while her husband worked so they could buy a house for themselves. Both of her jobs were with different cleaning companies. Slavica and Jadranka both found jobs cleaning at a local hospital. Branka worked while going to ESL (English as a Second Language) classes to learn English. Upon learning English she enrolled herself into a local Community College because her promotion at work hinged on her taking college level classes. All the participants took any jobs available to them; because having a steady paycheck meant that they could provide for their family. 
The participants and their families migrated to the U.S. in the mid 1990's. They came to America in search of a better life while escaping the war in Bosnia. Once they arrived, many were scared and experienced a fair amount of culture shock. Branka, who arrived in 1999 stated:

"First impressions of America? Well, it's hard to say. It was thirteen years ago so....everything felt very new, different. Different people, different culture, different food, different weather, simply put a person goes through this, what do the American's call it....culture shock. I don't really know what else to say. I expected more I guess my expectations were higher than what the reality was....yes."

Confronting culture shock was common for many the participants in this study. Another commonality was a yawning gap between the expectations that they had of America and the reality they confronted after arriving. They expected America to be a place where they could immediately find jobs and live a life similar to the one they lived in their country of origin. They also expected financial help while they settled into their new lives. When this did not happen panic set in. Desa mentions a desire to go back to Bosnia after spending only a week in the United States:

"I was horrified. I was surprised. I was surprised that they had homeless people all over the streets. I was surprised that people that were mentally ill were not being taken care of. There was no free medical aid for people. There was no monetary help for us. We had half of our rent paid for and we had 350 dollars in food stamps and that's all we had. I just remember wondering if these people cannot take care of their own people, of the homeless people on the streets, how in the hell are they going to help us. I mean I wanted to go back. I wanted to go back and I asked to go back, but it was too late so we had to find jobs immediately. We had 20 days to find jobs to support ourselves and our kids." 
Although Desa is an extreme case, the other participants also spoke about being disappointed when first coming to America. They were disappointed because they had just come from a country where schooling was free and medical expenses were not as large as they were here. An additional common challenge that they all confronted was the need to find employment almost immediately. Because they did not speak English finding similar jobs to those they had in Bosnia was extremely difficult. The families quickly realized that in order to survive and eventually prosper both the husband and the wife needed to find employment. Slavica, who came to the United States with her husband and a 4 year old child, describes this situation:

"In Bosnia you could live with one paycheck, because most of the households were like that. A lot of women could stay at home and the family would be fine. Here (in Portland) it's a different story, here...well there people would build their own houses, or they would live in their small apartment. Here while you're making payments on your house......you can't do it with one payment. If you want a good life for your family then both people have to work. Two paychecks are necessary."

Slavica echoes the opinion of all the participants in this study. They all believed that both the husband and wife needed to find employment in order to sustain the lifestyle that they were accustomed to. This experience mirrors the experience of Bosnian refugees that resettled in New York and Vienna in the mid 1990's who were also able to find jobs quickly (Franz, 2003).

\section{Division of Household Labor in America}


Coming to America forced the participants to find any jobs they could in order to survive. The whole family was under pressure to bring money into their household. The focus on survival of the family played a significant role in how the labor between these couples was divided within the households. On the surface, the participants were not preoccupied with the maintenance of gender roles. Their primary focus was on prosperity and the opportunity for a better life. Slavica stated: 'every paycheck was needed'. This meant that the jobs that men and women held outside of the home were equally important.

The constant stress forced the men to become more involved in doing the household chores. The women believed that it in order to handle the stress in their newfound environment they would have to work with their husbands in every aspect of their lives. They believed that the husbands shared these same ideas about working together. This is the reasoning given for the women taking on multiple and often times physically strenuous jobs such as maid or housekeeper. This also the reasoning Slavica used for the husband's increased participation in doing household chores:

"Here (In Portland) life is such that you go to work and then you come home. There is nothing else. So we both work, but as far as the home we do a lot more things together. Here (In Portland)we don't have the idea that it is the woman.....that she is the one that has to take care of the house all the time. I mean he helps me a lot more now than he did back then, but that has to happen. I come home from work exhausted and I can't do all the work after that."

Slavica worked as a cashier in Bosnia and stated that her job was necessary for the survival of her family, much like her job as a cleaning lady at a local hospital is necessary 
for survival of her family in the United States. Slavica however notes that while she was living in Bosnia her husband was a lot less involved in the participation and completion of the household chores. This means that he is not more helpful because of her job status. It seems that his increased participation in helping out within the house is due to the increased stress she feels at work in the United States as opposed to Bosnia.

The stress of working in the United States was much different for the participants than the stress of working in Bosnia. In the United States the participants felt that they had to say yes to any job that was offered to them in order to provide for their family. They were also surrounded by co-workers who did not speak the same language as they did, which caused them additional tension. The fast pace of work in the U.S., and the pressure to keep one's job were additional factors that caused the participants unexpected stress; this is something that Branka identified with:

"My experience working here in the United States is that....here there is so much pressure on people. People are afraid to lose their jobs. In Bosnia people worked at their jobs and never thought about losing them or being fired. Here there is a big fight for survival. Everyone is looking to get ahead at the expense of someone else. How do I say this...it's as if, if I wanted something I would have to be willing to walk over you to get it. That seems to be the mentality here. When you combine that with the fast pace of work and working with people that don't share the same language or culture with you....it makes you feel down."

The hectic schedule and job stress impacts child-rearing practices. In Bosnia it was the mother's responsibility to be in charge of child rearing. All of the participants said that they were more involved in their children's lives while living in Bosnia than they are here. A main reason given for this is the hectic job schedule. The impact that this 
decrease of involvement on the mother's part has is that it forces the fathers to take on more responsibilities in child rearing.

Seka, who worked a part time job in Bosnia and took on the primary responsibility in child rearing, now works the night shift as a cleaning person at a local hospital. She has had this job since her arrival to Portland 16 years ago. She has 2 daughters who have now moved out of the family home, but she recalls the idea that her husband was the one who took on the primary responsibility in raising the girls after they arrived in Portland;

"Because my husband works all day, he came home at around the same time as the children. So he was the one responsible for the kids.

Absolutely! He took them to play tennis, he took them wherever they needed to go, he helped with their homework, he disciplined them if that was necessary. He is a wonderful father, as far as that is concerned I couldn't be happier with him. As far as his involvement with the kids here (In Portland), I am extremely satisfied."

The hours Seka worked clearly limited time with her children. It was necessary for her husband to get more involved than he was in Bosnia, as was the case with other husbands in this study. If the wife was unavailable because of her work responsibilities or because of general exhaustion as it related to her work hours, the husbands did pick up the slack especially when it came to child rearing, because wives were unable to due to lack of availability.

The American culture also seems to play a role in how the household labor is divided between the couples. The level of involvement that father's had with their children is particularly affected by the American culture. Jadranka, who had stated that 
while in Bosnia her husband's role with the children was defined with him playing games with them and taking them on trips, explains how the American culture changed what his responsibilities were towards their two children; a teenage son and a six year old daughter:

\begin{abstract}
"Here (In Portland) we both help out with the children. I am still in charge of raising them, but he helps out a lot more. In America that's normal. It's normal for a father to take a baby and change his diapers. That's something unseen where we're from. Where we are from (Bosnia) the women take care of the children. She bathes them and feeds them. Here the man is allowed to take care of the children more. So I think he took care of them more here than he would at home. I mean our son was older so all he had to do there was find help find him a job, but our daughter was young and he was very present as a parent in her life."
\end{abstract}

Each participant had children at home in Bosnia, and each participant migrated with their children to the United States. This meant that the participants had to take care of their children both in Bosnia and for a time in the United States. Taking care of the children was a part of the division of household labor, and in Bosnia it was a part that the woman was fully responsible for. According to Jadranka, a man doing basic chores that pertain to the children such as changing their diapers was unheard of. Jadranka also talks about her husband's increased involvement with the children being the direct effect of living in America. According to her, in the American culture the husband is expected to be involved more with the children. Because of this expectation her husband did become more involved and thusly increased his participation in household labor.

After moving to the United States men took on a greater responsibility within the home, particularly when it came to raising children. This change did not happen because 
of greater overall gender equality. The change did occur because of the culture shock as well as the newfound stress the participants dealt with from the jobs they took on. The stress and culture shock forced the couples to focus more on prosperity rather the maintenance of gender roles that they established in Bosnia.

This finding contradicts previous research (Bell, 2001; Franz, $2000 \&$ 2003; Sossou, 2008) that stated that after migration men and women adhered to traditional gender roles and that men did not get involved in helping women within the home. The table below illustrates how men's involvement in the division of household labor changed after the families migrated.

\section{Change in Gender Relations}

According to the participants in this study, household labor was seen as woman's work in Bosnia. After their arrival to America men did start contributing more because of stressors that the family experienced. However this does not mean that the general view of household labor being woman's work changed.

The help that Bosnian women received within the household from their husbands was not in an effort to subvert their traditional gender roles, but happened out of necessity and the need to survive. By assigning the wife particular tasks that she was always responsible for, the couples were recreating a new version of traditional gender roles that they were accustomed to in Bosnia.

Overall the men contributed more, however every wife had a specific task that she was assigned that was fixed. This means that in each family the wife performed a particular chore every time regardless of her availability, work schedule or interest in the 
task. Zorica, the woman who had mentioned that her husband pays for the bills because he has a man's brain mentioned this idea:

"My husband helps a lot more now. He does the dishes more often now, and it's not because I make him do it. He does them on his own. Things like ironing though....no, no, no he won't do that. I don't ever want to do that, but he should definitely not have to do it."

Although her husband is more involved in the completion of chores overall, the chores that neither one of them wanted to fall on woman's shoulders. Ironing the clothes is one that she has to do every time. Other tasks that she mentioned being completely responsible for were cleaning the bathroom and washing the clothes. By making sure that the wife is responsible for certain chores at all times, the couples are re-creating a form of the division of household labor that they had back in Bosnia. Instead of everything within the household being classified as 'woman's work', the specific tasks that the women do each day become 'woman's work'. Jadranka, whose husband had increased his involvement with the children after moving to the United States spoke about how this happens in her family:

"Now he helps decide what groceries need to be bought. He will make lunch and dinner sometimes. We make a lot more of the decisions together now (In America) than we did before (In Bosnia). However I still am responsible for cleaning the house and doing the dishes, the laundry and things like that. Those are my responsibilities. That is my job.”

Once again the husband does do more chores within the household than he did in Bosnia; however she has certain responsibilities that are only hers. When she was asked about 
any jobs that are only her husband's, she mentioned that he is solely responsible for mowing the lawn and paying the bills on time. The husband is responsible for the physically demanding jobs and the financial responsibilities. The wife is assigned specific chores that she completes alone. This was something that happened in every household. Every one of the women interviewed spoke about their husband's greater involvement in household chores, and the fact that certain chores were always done by women.

This finding is consistent with previous research (Bell, 2001; Franz, 2000 \& 2003; Sossou, 2008) in that men held on to the identities that they held in Bosnia and expected the women to do the same. According to the participants in this study men changed some of their behaviors and helped more within the households, but the overall ideas about what specific things men and women were responsible for remained unchanged.

\section{Comparison with other Bosnian Immigrants}

The participants in this study understand their experience as it relates to the division of household labor to be very similar to other immigrant Bosnian households in Portland. All 10 participants stated that the way they divided household labor could be generalized to other Bosnian immigrant households in Portland. The participants did not think that there was something unique or different between how they divided household labor from other Bosnian couples that they knew. The reason that most felt the division is the same across Bosnian immigrant households in Portland is because job stress and the hectic pace of life In the U.S. affects all Bosnian immigrant couples in the same way. Magda identified with this idea: 
"I think that most Bosnian people that come here (to America) have to help each other more at home. Life is so fast and someone is always working that men help more at home (in America). I think this is the same for all the Bosnians I know. We all came here and we all had to adjust to the speed of this life, life wasn't adjusting for us....so I think how we do things at home is the same as how other Bosnians do things at home. There might be subtle differences, but really it's all the same thing."

The participants believed that the pace of life and the hectic work schedule was impacting all Bosnian immigrant families living in Portland the same way. The participants assumed that men were responsible for doing more chores in Portland than they did in Bosnia, and they believed that this is true for all other immigrant Bosnian households in Portland.

\section{Comparison with American Households}

The participants assumed that their experience with the division of household labor was similar to other Bosnian immigrant families in Portland, but they were did not compare themselves to American households. Most said that they did not know how American people living in Portland divided the labor within their home:

"What do I know? I don't know how Americans do things in their homes. I just know how I do things in my home and I know how we (the Bosnian people) do things here. I know my life and how we divide things. I don't know anything about the way they do things in their own homes."

Malina expresses an opinion that was echoed by most women in this study. She believed that she did not know enough American people to understand how things worked in their homes. Many women in this study also spoke about not having many close friends that 
were American. To them, this lack of American friends meant that they could not accurately judge how American people divided household labor within their homes.

Branka was the only participant to compare how Bosnian immigrants in Portland divide household labor to how Americans in Portland divided it. She believed that American households had absolute equality within their homes and that this is something that Bosnian immigrants should strive to achieve:

"I think that there are probably exceptions to every rule, but I think people in Portland...American people help each other. I think here the work at home is equal for both men and women, and I think there are some reasons that our (Bosnian) men help more now that they are here (in America), but I think it's going to take some time before they help out as much as Americans (American men) do. I think as time passes Bosnians living here will also divide things equally at home"

Branka thinks that American men in Portland divide household labor equally with their wives. She believes that Bosnian men living in Portland have increased the amount of work they do at home after migrating to the U.S., and that they will eventually do as much work within the home as the American men. She is the only participant that believed that migration alone changed how much work men did within the home.

\section{Conclusion}

In Bosnia women were responsible for the completion of the household chores which included; meal preparations, cleaning and the majority of child rearing. They were responsible for these chores regardless of their work status. Men were expected to provide financially for the family. The household chores that men were responsible for were the ones deemed more physically demanding ones such as; fixing household 
appliances, mowing the lawn and general home repair. The one household that had the most equal division of household labor was the only household that had numerous people whose well-being was dependent on the presence of an adult.

After migrating with their families to the United States, men became more involved in helping their wives with various chores around the household. They did not become more involved because of their interest in gender equality, but because the stress of establishing a life in a foreign country, provide for their families and be financially stable was effecting their household and helping out became a necessity.

The couples recreated a gender division within their homes by assigning specific tasks that the wife would be responsible for constantly. It was a way for the wife to perform the same gender role in a new setting on a lesser scale. The help men provided was done out of necessity and not out of a desire to change gender roles.

Wives understood their experience as it relates to the division of household labor as being similar from other Bosnian wives living in Portland. The participants did not compare the way they divide household labor in their home to U.S. couples. 


\section{Chapter 5}

\section{Discussion and Conclusion}

Bosnian immigrant women in this study described themselves as being the ones in charge of doing the housework while living in Bosnia. They assumed that it was their responsibility to take care of the home regardless of if they had a job. The husband's involvement in the household tended to be limited to doing general home repairs and paying the bills. The participants adhered to traditional gender expectations of what a wife was supposed to do in Bosnia.

After moving to the U.S. the participants felt the immediate need to find jobs in order to survive and eventually prosper. This meant that the husband and wife took any jobs that were offered. The participants experienced increased job stress due to not being able to speak the same language as their co-workers, working long hours and feeling like they had to keep these jobs in order to be financially stable. Job stress coupled with the culture shock after the arrival to the U.S. played a key role how the division of household labor shifted. Because the participants were so stressed, they had less time and energy to devote to doing all of the work within the home. Their husbands were forced to increase their involvement. Overall, wives still did the more of the household labor postmigration, but husbands' involvement had increased.

The participants believed that the way they divided household labor was similar to other Bosnian households. They presumed that other Bosnian couples were going through similar stresses which forced them to make similar adjustments within the households. None of the participants pointed to any stark differences between themselves and any 
other Bosnian immigrant couple in Portland. The participants felt an affinity to other Bosnian immigrants in Portland and believed that they understood their experiences.

The participants did not think that they could compare how they divide household labor within their homes to how U.S. couples divide household labor. Many spoke about not having American friends or knowing how a 'typical American household' functions. This may be because the participants did not see themselves as Americans, despite the length of time spent in the U.S. They felt like they understood how things functioned in Bosnian households because they identify more with their Bosnian identity.

Ultimately, the women I interviewed had an essentialized view of gender. Bosnian refugees transferred and adapted rather than completely changed their traditional gender roles and behavior patterns in their host societies. They had the same view of gender roles post migration that they had prior to it, but in the United States men needed to help out with chores more because women did not have the same amount of time to complete them that they had in Bosnia. None of the Bosnian women in my sample complained about their household work and only asked for help from their husbands if they absolutely had to. Bosnian women in my sample liked being mothers, and in some cases see daily chores, such as cooking traditional meals, as a good thing even if it means working a double shift at their job site and at home. Given their life experiences and the context under which they came to the United States, no Bosnian woman of my sample wanted to achieve individual emancipation or even economic independence from her husband or families. The progress of the entire family remained at the center of Bosnian women's ambitions. The women in my sample came to the United States to continue the life they had in Bosnia, not to change the lives they had there. This rejection of Western 
feminist values and the maintenance of traditional family values is not surprising when one considers Bosnian immigrant women come from a culture in which the family is the central and in many cases, is dominated by the female in household issues and decisions. They embrace wage labor not because they seek independence from their male partners by active engagement in the public sphere or because they want to escape the oppressive patriarchal traditions in their home. They work outside the home simply out of economic necessity.

In order to fully understand what happens with the division of labor within migrant populations, researchers must analyze these populations from both a gender and a migration perspective. My findings do not support the position that is often put forth by feminist scholars who assume that work liberates migrant women in Western societies (Davis and Sherman Heyl, 1986; Lamphere et al., 1993; Pessar, 1995; Espiritu, 1997) The feminist perspective must incorporate of migrant's historical, cultural, and socioeconomic experiences and the immigrant women's own construction of their current lives. Migration research on the other hand, must incorporate the experience of women into their research at a greater rate. Women have been primarily excluded from migration research until the 1980's.

This study adds to the literature on gender and migration because it examines at a population previously unexamined in this area of the country. In the past Bosnian women have been interviewed on various topics (Brajdic-Vukojic, (2007); Franz, 2003; Huisman and Hondagneu-Sotelo, 2005; Hunt, 2004; Adelamn et al.; 2008) but very few studies focused on the changes in the division of household labor after the Bosnian women 
migrated (Franz 2003). This study however focused on the experience of Bosnian women in New York and Vienna.

Further research on this topic needs to address how the husbands feel about the division of household labor. The voices of men must be included if we want a complete family experience as it relates to migration and the division of household labor. Further research should also examine how the division of labor plays out amongst second generation Bosnian immigrants. Perhaps the second generation immigrants acclimate to the American culture and divide the household labor much differently from their parents. Other immigrant women from Bosnia and other Eastern European countries should also be asked about how migration impacted the way they divide household labor. By doing this we could examine if the experience of Bosnian women interviewed in this study is similar to that of other Bosnian and other Eastern European women in the U.S. 


\section{References:}

Abdulrahim, D. (1993). "Defining gender in a second exile: Palestinian women in West Berlin.” Migrant women: Crossing boundaries and changing identities, 155.

Adelman, M, Gregory C; Erez, E. (2008) "Intersections of Immigration and Domestic Violence : Voices of Battered Immigrant Women.” Feminist Criminology, 4:32.

Ahmad, A. (1995). "Role conflict and coping behaviour of married working women." Pertanika Journal of Social Sciences \& Humanities 3.2 (1995): 97-104.

Berk, S. F. (1985). The gender factory: The apportionment of work in American households. New York: Plenum Press.

Bhalla, V (2008). "Couch Potatoes and Super-Women": Gender, Migration, and the Emerging Discourse on Housework among Asian Indian Immigrants". Journal of American ethnic history, 27:4-71.

Bianchi, S. M., Robinson, J. P., Milkie, M. A. (2006). "Changing rhythms of American Life" Russell Sage foundation, New York.

Bielby, W. T., \& Bielby, D. D. (1989). "Family ties: Balancing commitments to work and family in dual earner households." American Sociological Review, 776-789.

Blair, S. L., \& Johnson, M. P. (1992). "Wives' perceptions of the fairness of the division of household labor: The intersection of housework and ideology." Journal of Marriage and the Family, 570-581.

Blair, S. L., Lichter, D. T. (1991). "Measuring the division of household labor: Gender segregation of housework among American couples." Journal of Family Issues, 12:91-113.

Brajdic-Vukojic M. (2007). Between Tradition and Modernization: Attitudes Toward Women's Employment and Gender Roles in Croatia. International Journal of Sociology, $37,32-53$.

Brines, J. (1994). "Economic dependency, gender, and the division of labor at home." American Journal of Sociology, 100:652-88.

Calasanti, T. M., \& Bailey, C. A. (1991). "Gender inequality and the division of household labor in the United States and Sweden: A socialist-feminist approach." Soc. Probs., 38, 34

Charmaz, K. (2006) Constructing Grounded Theory: A Practical Guide. Sage Publications 
Chavez, L. (1994). "The Power of the Imagined Community: The Settlement of Undocumented Mexicans and Central Americans in the United States," American Anthropologist, 96( 1):52-73.

Coleman, M. T. (1988). "The Division of Household Labor Suggestions for Future Empirical Consideration and Theoretical Development." Journal of Family Issues, 9(1), 132-148

Colic-Peisker, Val and Walker, Iain. (2003). "Human Capital, Acculturation and Social Identity:

Bosnian Refugees in Australia." Journal of Community \& Applied Social Psychology, 13:337-360.

Coltrane, S. (2000). "Research on household labor: modeling and measuring the social embeddedness of routine family work." Journal of Marriage and the Family, 62:12081233.

Cotter, D. A., Hermsen J.M, \& Vanneman R. (2004). Gender inequality at work. New York: Russell Sage Foundation.

Coverman, S. (1983). Gender, domestic labor time, and wage inequality. American Sociological Review, 623-637

Coverman, Shelley, and Joseph F. Sheley. (1986) "Change in men's housework and childcare time, 1965-1975." Journal of Marriage and the Family (1986): 413-422.

Coverman, S, Sheley J. . (1986) "Change in men's housework and child-care time, 19651975." Journal of Marriage and the Family (1986): 413-422.

Davis, J. and Sherman Heyl, B. (1986) 'Turkish women and guest worker migration to West Germany'in R.J. Simon and C. Brettell (1986) editors, International Migration: The Female Experience" Totowa, NJ: Powman \& Allanheld Publishers, pp.178-196.

DeLaet, D. L. (1999) "Introduction: The Invisibility of Women in Scholarship on International Migration." Gender and Immigration. Ed. G. A. Kelson and D. DeLaet. New York: New York University Press. Pp. 1-17.

DeMeis, D. K., \& Perkins H. (1996) "Supermoms" of the Nineties Homemaker and Employed Mothers' Performance and Perceptions of the Motherhood Role." Journal of Family Issues 17.6 776-792.

Eastmond, M. (1993). "Reconstructing Life: Chilean Refugee Women and the Dilemmas of Exile" Migrant Women Crossing Boundaries and Changing Identities Oxford: Berg 
England, P. (1992). Comparable worth: Theories and evidence. New York: Aldine.

England, P, Garcia-Beaulieu C \& Ross M. (2004). «Women's employment among Blacks, whites, and three groups of Latinas: Do more privileged women have higher employment?" Gender \& Society 18 (4): 494-509.

England, P, and McClintock A.. (2009). "The gendered double standard of aging in U.S. marriage markets." Population and Development Review 35:797-816.

England, P. "The Gender Revolution Uneven and Stalled." (2010) Gender \& Society 24.2 (2010): 149-166.

Espiritu, Y.L. (1997) "Asian American Women and Men: Labor, Laws, and Love" Thousand Oaks, CA: Sage.

Erlich, V. (1976) Family in Transition, Princeton: Princeton University Press.

Franz, B. (2000) "Ethnic identity and gender roles in flux: the adaptation of Bosnian refugees to theAustrian systems of humanitarian relief and economic integration" 1992 1999' e-merge, January 2000: http://www.carleton.ca/emerge/v1_art/v1_fran/v1_fra1.html.

Franz, B (2003). "Bosnian Refugee Women in (Re)Settlement: Gender Relations and Social Mobility." Feminist review, 73:86-103

Foner, N. (1986) "Sex roles and sensibilities: Jamaican women in New York and London' in R.J. Simonand C. Brettell (1986) editors, International Migration: The Female Experience, Totowa, NJ: Powman \& Allanheld Publishers, pp.133-150.

Gager, C. T. (1998). "The role of valued outcomes, justifications, and comparison referents in perceptions of fairness among dual-earner couples." Journal of Family Issues, 19:622-648.

Gamburd, M. R. (2000). The kitchen spoon's handle: Transnationalism and Sri Lanka's migrant housemaids. Cornell University Press,

Gershuny, J., \& Robinson, J. P. (1988). "Historical changes in the household division of labor.” Demography, 25(4), 537-552.

Goldring, L. (2001). "The Gender and Geography of Citizenship in Mexico-U.S. Transnational Spaces," Identities: Global Studies in Culture and Power, 7(4):501-537. 
Hagan, J. M.(1994). Deciding to Be Legal: A Maya Community in Houston. Philadelphia: Temple University Press.

Hamilton, L, \& Armstrong A. A. (2009). "Gendered sexuality in young adulthood:

Double binds and flawed options." Gender \& Society 23:589-616.

Hiller, D.V. (1984). "Power, Dependence and the division of family work. Sex Roles, 10, 1003-1019.

Hirsch, J. (1999) "En el Norte la Mujer Manda: Gender, Generation, and Geography in a Mexican Transnational Community," American Behavioral Scientist, 42(9): 1332-1 349.

Hochschild, A.R. (1983). "The Managed Heart: Commercialization of Human Feeling." University of California Press. 90.

Hoschild, A. R. (1989). “The Second Shift.” University of California Press, Berkeley. Hondagneu-Sotelo, P. and M. Messner (1994) “Gender Displays and Men's Power: The 'New Man' and the Mexican Immigrant Man.” Theorizing Masculinities. Ed. H. Brod and M. Kaufman. Thousand Oaks, CA Sage Publications.

Hood, J. C. (1986) "The provider role: Its meaning and measurement." Journal of Marriage and the Family: 349-359.

Huisman, k; Hondagneu-Sotelo, P. (2005). "Dress Matters : Change and Continuity in the Dress Practices of Bosnian Muslim Refugee Women." Gender and Society, 19:44.

Jones-Correa, M. (1998). Between two nations: The political predicament of Latinos in New York City. Cornell University Press.

Kamo, Y. (1988). "Determinants of household division of labor: Resources, power, and ideology." Journal of Family Issues, 9: 177-200.

Kibria, N. (1993) Family Tightrope: The Changing Lives of Vietnamese Americans. Princeton: Princeton University Press.

Kilbourne, B. S, England P, Farkas G., Beron K, \& Weir D. (1994). "Returns to skills, compensating differentials, and gender bias: Effects of occupational characteristics on the wages of white women and men." American Journal of Sociology 100:689-719.

Kyle, D. (2000) Transnational Peasants: Migrations, Networks, and Ethnicity in Andean Ecuador. Baltimore: The Johns Hopkins University Press.

Lamphere, L., Zavella, P. and Gonzales, F. with Evans, P. (1993) "Sunbelt Working Mothers" Ithaca, NY: Cornell University Press. 
Major, B. (1993). "Gender, entitlement, and the division of family labor." Journal of Social Issues, 49:141:159.

Marshall, C. and Rossman, G. B. (2010). “Designing Qualitative Research” Sage Publications, Inc.

Mehrotra, M. (2010). "The Family as a Site for Gendered Ethnic Identity Work Among Asian Indian Immigrants". Journal of Family Issues. 31 (6) 778.

Morokvasic, M. (1984) “Birds of Passage Are Also Women,” International Migration Review, 18(4):886-907.

Morokvasic, M. (1986) '"Being a women in Yugoslavia: past, present and institutional equality' in M. Gadant (1986) editor, Women of the Mediterranean, New Jersey: Zed Books Ltd, pp.120-138.

Ong, A. (1999). Flexible Citizenship: The Cultural Logics of Eansnationality. Durham, NC: Duke University Press.

Pessar, P. (1995) 'On the homefront and in the workplace: integrating immigrant women into feminist discourse' Anthropological Quarterly, Vol. 68, No. 1: pp.37-47.

Pessar, P R. (2001) 'Women's Political Consciousness and Empowerment in Local, National, and Transnational Contexts: Guatemalan Refugees and Returnees," Identities: Global Studies in Culture and Power, 7(4):461-500.

Pessar, P. R., \& Mahler, S. J. (2003). “Transnational migration: Bringing gender in.” International Migration Review, 37(3), 812-846.

Petkova, B. and Griffin, C. (1998) "Bulgarian women and discourse about work" The European Journal of Women's Studies, Vol. 5,437-452.

Pribilsky, J. (2004). “'Aprendemos A Convivir': Conjugal Relations, Co-parenting, and Family Life among Ecuadorian Transnational Migrants in New York and The Ecuadorian Andes." Global networks, 4(3), 313-334.

Prieto, Y. (1986) 'Cuban women and work in the United States: a New Jersey case study' in R.J.

Simon and C. Brettell (1986) The Female Experience, Totowa,NJ: Powman \& Allanheld Publishers, pp.95-112. 
Robinson, John P., and Geoffrey Godbey. Time for life: The surprising ways Americans use their time. Penn State Press, 1997.

Ross, C. E. (1987). “The division of labor at home.” Social Forces, 65: 816-833.

Rouse, R. (1995). "Questions of Identity: Personhood and Collectivity in Transnational Migration to the United States," Critique of Anthropology, 14(4):35 1-380.

Shelton, B. A., John D. (1996). "The division of household labor." Annual Review of Sociology, 22: 299-322.

Simic, A. (1999) 'Machismo and cryptomatriarchy: power, affect, and authority in the traditional

Yugoslav family' in Gender Politics: In The WesternBalkans, University Park: The Pennsylvania State University Press, pp.11-30.

Simon, R.J. and Brettell, C. (1986) The Female Experience, Totowa, NJ: Powman \& Allanheld Publishers.

Sossou, M-A., Craig D. C, Heather O. and Michelle S. (2008). "A Qualitative Study of Resilience Factors of Bosnian Refugee Women Resettled in the Southern United States." Journal of Ethnic and Cultural Diversity in Social Work, 17(4):365-385

Spradley, J. S. (1979). “The Ethnographic Interview” New York: Holt, Rinehart \& Winston.

Strauss, L. A., Corbin, J. (1998) "Basics of Qualitative Research Techniques and Procedures for Developing Grounded Theory." Sage Publications. London

Thompson, L. (1991). “Family Work: women's sense of fairness.” Journal of Family Issues, 12:181-196.

Thompson, L., \& Walker, A. J. (1989). "Gender in families: Women and men in marriage, work, and parenthood." Journal of Marriage and the Family, 845-871.

Twiggs, J. E., McQuillan J. \& Feere. M (1999). "Meaning and Measurement: Reconceptualizing Measures of the Division of Household Labor." Journal of Marriage and the Family, 61:(712-724)

US Congress Joint Economic Committee. (2010). "Women and the Economy 2010: 25 Years of Progress but Challenges Remain.” Retrieved March 16, 2012. http://jec.senate.gov/public/?a=Files.Serve\&File id=8be22cb0-8ed0-4a1a-841baa91dc55fa 81 
Vidal de Haymes, M. R. (1992). "Paid Work and Housework: Cuban Women in the United States". Society for the Study of Social Problems.

Weingarten, K (1978). "The employment of professional couples and their distribution of involvement in the family" Psychology of Women Quarerly, 3, 43-52

West, C, Zimmerman, D.H. (1987). “Doing Gender.” Gender \& Society, 1:125-151. 
Appendix

Interview Questions

Questions about the participant's lives:

When were you born?

Where were you born?

When did you come to the United States? To Portland?

What is the highest level of education you completed? Was this completed in Bosnia or in the United States?

What is your marital status?

Were you married in Bosnia? To the same person you are married to currently?

Do you have children? How many?

Questions about coming to the United States:

Tell me about the experience of coming to the United States from Bosnia.

Possible follow up questions

Who did you come to the United States with?

How were you able to come to the United States?

Did you live somewhere other than Bosnia before coming to the United States? What was that experience like?

After moving to the United States, did you always live in Portland?

If not, where else have you lived? Why did you decide to come to Portland?

How long have you lived in Portland?

Questions about life in Bosnia:

In your own words tell me about what life was like in Bosnia?

Possible follow up questions

Did you have a job outside of the home while living in Bosnia?

How many jobs did you have and what were they?

Was this job necessary for survival of the family?

Did the husband work?

What was his job?

If you had a choice would you prefer to work or not work?

How many people lived in your household in Bosnia (children included)?

When living in Bosnia did you live in an apartment or a house?

Did you won a car in Bosnia?

How did your family divide the time spent on childcare and household chores?

Prompts for previous question:

How was time divided on the following chores? 
1) Who prepared the meals for the family?

-Breakfast

-Lunch

-Dinner

2) Who did the household laundry?

3) Who ironed the clothes?

4) Who cleaned the home?

-vacuum

-dust

-sweep/mop

-clean the bathroom

5) Who went shopping for groceries?

6) Who did the dishes?

7) Who took care of the pet(s)?

8) Who was responsible for child care?

9) Who was responsible for the repairs at home?

10) Who paid the bills?

Were there chores that a third party did regularly? (children, maid, housekeeper)

Questions about life in America:

In your own words tell me about what life is like here in Portland now?

Possible follow up questions

Do you have a job outside of the home here in Portland now?

Where do you work?

Have you worked in other jobs? What were they?

Is this job necessary for survival of the family?

Does the husband work?

Where does he work?

Has he worked other jobs? What were they?

If you had a choice, would you prefer to work or not work?

Do you own or rent your home here in the United States? (This will not be asked of people living in an apartment.)

Do you own a car now?

How many people live in your household (children included)?

How does your family divide the time spent on childcare and household chores?

Prompts for previous question:

Who does the following within the household?

1) Who prepares the meals for the family now?

-Breakfast

-Lunch 
-Dinner

2) Who does the household laundry?

3) Who irons the clothes?

4) Who cleans the home?

-vacuum

-dust

-sweep/mop

-clean the bathroom

5) Who goes shopping for groceries?

6) Who does the dishes?

7) Who takes care of the pet(s)?

8) Who is responsible for child care?

9) Who is responsible for the repairs at home?

10) Who pays the bills?

Are there chores that a third party does regularly? (children, maid, housekeeper)

Concluding questions:

Do you think expectations for how household labor is divided is different in Portland from the Bosnia?

How are they different?

How are they the same?

Do you think your experience is similar to the experience of other Bosnian immigrant households in Portland?

How is it similar?

How is it different?

What are the major differences between life here and life in Bosnia?

What parts of living in Bosnia do you like better than in the United States?

What parts of living in United States do you like better than in the Bosnia?

What is the difference between your family life here and your family life in Bosnia?

If you work here and worked in Bosnia; what is the difference between working here and in Bosnia?

Is life financially better for you and your family here or in Bosnia?

Is there anything else you would like to add that you were not able to say during the course of the interview? 